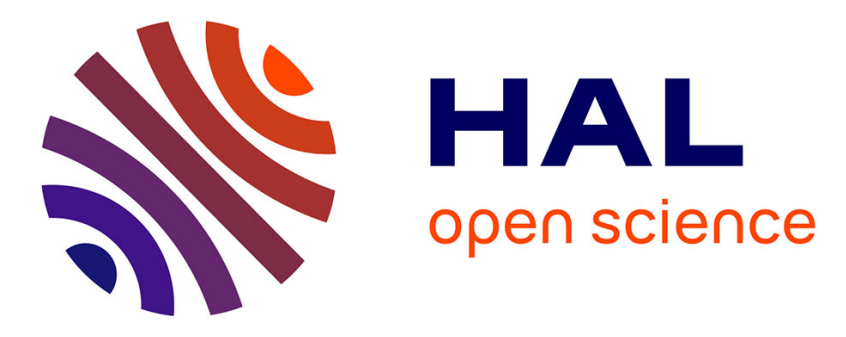

\title{
The consistency of visual sewer inspection data
}

J. Dirksen, F.H.L.R. Clemens, H. Korving, Frédéric Cherqui, Pascal Le

Gauffre, T. Ertl, H. Plihal, K. Müller, C. T.M. Snaterse

\section{To cite this version:}

J. Dirksen, F.H.L.R. Clemens, H. Korving, Frédéric Cherqui, Pascal Le Gauffre, et al.. The consistency of visual sewer inspection data. Structure and Infrastructure Engineering, 2011, pp.1-15. 10.1080/15732479.2010.541265 . hal-00663958

\section{HAL Id: hal-00663958 \\ https://hal.science/hal-00663958}

Submitted on 27 Jul 2012

HAL is a multi-disciplinary open access archive for the deposit and dissemination of scientific research documents, whether they are published or not. The documents may come from teaching and research institutions in France or abroad, or from public or private research centers.
L'archive ouverte pluridisciplinaire HAL, est destinée au dépôt et à la diffusion de documents scientifiques de niveau recherche, publiés ou non, émanant des établissements d'enseignement et de recherche français ou étrangers, des laboratoires publics ou privés. 


\title{
The consistency of visual sewer inspection data
}

J. Dirksen a,b , F.H.L.R. Clemens ${ }^{\text {a,c }}$, H. Korving ${ }^{\text {a,c }}$, F. Cherqui ${ }^{\text {d }}$, P. Le Gauffre $^{\mathrm{d}}$, T. Ertl ${ }^{\mathrm{e}}$, H. Plihal ${ }^{\mathrm{e}}$, K. Müller ${ }^{\mathrm{f}}$; C.T.M. Snaterse ${ }^{\mathrm{g}}$

${ }^{a}$ Department of Civil Engineering and Geosciences, Delft University of Technology, Delft, The Netherlands; ${ }^{b}$ Waternet, Amsterdam, The Netherlands; ${ }^{c}$ Witteveen + Bos Consulting Engineers, Deventer, The Netherlands; ${ }^{d}$ INSA Lyon, LGCIE, Villeurbanne, France; ${ }^{e}$ Institute of Sanitary Engineering and Water Pollution Control, University of Natural Resources and Life Science, Vienna, Austria; ${ }^{f}$ Research Institute for Water and Waste Management, RWTH Aachen University, Aachen, Germany; ${ }^{g}$ Snaterse Civiele Techniek \& Management, Ermelo, The Netherlands

j.dirksen@tudelft.nl

(Received $x x$ Xxx 20xx; final version received $x x X x x$ 20xx)

\begin{abstract}
In common with most infrastructure systems, sewers are often inspected visually. Currently, the results from these inspections inform decisions for significant investments regarding sewer rehabilitation or replacement. In practice the quality of the data and its analysis is not questioned although psychological research indicates that, as a consequence of the use of subjective analysis of the collected images, errors are inevitable. This paper assesses the quality of the analysis of visual sewer inspection data by analyzing data reproducibility; three types of capabilities to subjectively assess data are distinguished: the recognition of defects, the description of defects according to a prescribed coding system and the interpretation of sewer inspection reports. The introduced uncertainty is studied using three types of data: inspector examination results of sewer inspection courses, data gathered in day-to-day practice, and the results of repetitive interpretation of the inspection results. After a thorough analysis of the data it can be concluded that for all cases visual sewer inspection data proved poorly reproducible. For the recognition of defects it was found that the probability of a false positive is in the order of a few percent, the probability of a false negative is in the order of $25 \%$.
\end{abstract}

Keywords: Sewer inspection, Reproducibility, Uncertainty

\section{Introduction}

Visual sewer inspection is the primary investigation technique used in sewer system management. Decisions on the provision of the large investments associated with sewer rehabilitation and replacement are often based on the interpretation of visual inspection reports. These reports, as can be seen in figure 1 , occur in the first investigation stage and so impact on all future stages and therefore are an important factor in the sewer management process. Often in practice, and even in some research studies reported in the literature (e.g. Baur and Herz, 2002), the quality of the data is not questioned. Some papers on deterioration modelling stress the importance of data quality (Wirahadikusumah et al. 2001 Ariaratnam et al. 2001). However, a comprehensive evaluation of the quality of visual sewer inspection data has not yet 